\title{
Factorial Analysis of Perceptual Understanding of Researchers towards Animal Cloning
}

\author{
H. A. Manu*, H. R. Meena and B. N. Priyanka \\ Department of Dairy Extension Education, National Dairy Research Institute, \\ Karnal, Haryana-132001, India \\ *Corresponding author
}

\begin{tabular}{l} 
K e y w o r d s \\
$\begin{array}{l}\text { Animal Cloning, } \\
\text { Factor Analysis, } \\
\text { Research Institutes } \\
\text { and Perception }\end{array}$ \\
Article Info \\
$\begin{array}{l}\text { Accepted: } \\
\text { 25 February } 2020 \\
\text { Available Online: } \\
\text { 10 March } 2020\end{array}$ \\
\hline
\end{tabular}

A B S T R A C T

Cloning is the latest development of specific assisted breeding in animal husbandry. The use of novel food technologies like genetic modification technology, nanotechnology and food irradiation technology have received mixed responses from the public. Perception is the degree to which information or ideas are perceived by the respondents. In this present work the perception of researchers towards animal cloning was carried out. The total of 180 respondents for investigation was utilized. Since the study was focused on animal cloning an ex-ante research design was used. The perspective wise score of each of the 180 researchers from sample area was undergone to factor analysis by Exploratory Factor Analysis (EFA) method using SPSS version 23. Most of the respondents perceived that they will trust animal cloning if its approved from the Government of India with a weighted mean score (81.00) and ranked first, and respondents also perceive that animal cloning in food production is good for growth of economy (WMS 66.44). The perception of the individuals change from time to time and situation to situation hence there is desperate need of wide publicity to bring the changes in the perceptions of public about animal cloned produces.

\section{Introduction}

Food being a constitutive of both cultural and individual identity (Gaskell, et al., ) the likelihood of consuming such products is correlated with discrete features comprising individual characteristics, socio-demographic variables (gender, type of family, religion and family background) and perception of individuals (Aizakhi et al., 2011). Hallman et al., in 2003 conducted a work to find out public perceptions of GM foods. 50.00 per cent of participants had knowledge that GM products were sold in the store and 25.00 per cent known that they had eaten GM products.

Anderson et al., (2006) found that 50.00 per cent of respondents were worried about the unknown effects that GM products will have on our environment. More than half of 
respondents $(57.00 \%)$ thought that genetically modified products create environmental risks and only 28.00 per cent thought that genetically modified products were an efficient method of food production (Ayaz et al, 2011). Gaskell et al., in 2005 reported that genetically modified (GM) foods and irradiated foods technology may not be accepted unless the proposed benefits of the applications seem to be positive such as health benefits, lower pesticide residues, and more environmental friendliness. The public demonstrates a relatively neutral and even positive perception of nanotechnology with an emphasis on its benefits (Brossard et al., 2009; Cobb and Macoubrie, 2004; Gaskell et al., 2005).

The Asian Food Information Centre conducted interviews in 2002 with 600 consumers in China, Indonesia and the Philippines (AFIC, 2003). This research found the majority of consumers were aware of the presence of biotechnology-derived foods in their everyday diets and there were not worried about this situation.

A majority of consumer reported that they believed they had eaten genetically modified foods, took no action to avoid such products and were willing to try samples of genetically modified foods. Brooks et al., In 2011 used paired comparisons to find out consumers' awareness of and attitudes towards meat and milk from cloned cows and described that consumers were comparatively more aware of animal cloning than other reproductive tools; around 31.00 per cent of consumers were willing to consume meat and milk products from cloned animals.

A survey conducted by the Pew Initiative on Food and Biotechnology in 2004 found that 29.00 per cent of consumers indicated that they would purchase meat and milk from the offspring of cloned animals, but 35.00 per cent indicated that they would never buy milk from the offspring of cloned animals (Mellman Group, 2006). The potential for individuals to use the facts for their own health advantage or service are generally have positive attitudes towards genetic testing. Attitudes towards genetic testing vary with age, gender and educational level. Overall, younger people found to be have a higher attention in genetic testing, and have high positive attitudes. Men seem to have more positive attitudes towards testing (Laegsgaard, 2008).

Molster et al., (2009) stated that higher the education higher the levels of genetic knowledge, which is related with a more promising attitude towards genetics in some work. Condit (2010) reported that more detailed information on the application of genetic tests may result in more concern and ambivalence.

The work conducted by Kasmo et al., (2015) on the perception of human cloning among the Malaysian respondents showed that less than 58.20 per cent of the respondents perceived that human cloning is against religion and the perception is different from one religion to another religion.

\section{Materials and Methods}

The present study was conducted in total four premier research institutes of India, two ICAR research institutes i.e., ICAR-National Dairy Research Institute, Karnal and ICAR-Indian Veterinary Research Institute, Izatnagar and two state veterinary universities i.e. Tamil Nadu Veterinary and Animal Science University, Chennai and Karnataka Veterinary, Animal and Fisheries Sciences University, Bengaluru. From each institute 30 students (M.Sc/M.V.Sc/Ph.D) and 15 scientific faculties (scientist/professors) from Production, Processing, and Management 
groups were selected randomly. Thus making total sample size 180 respondents for investigation. Since the study was focused on animal cloning an ex-ante research design was used. The data were collected through face to face interview through pretested semistructured interview schedule.

Perception towards animal cloning is the degree to which information or ideas are perceived by the respondents about animal cloning (Parameswaranaik, et al., 2015). Individual's perception about animal cloning was measured by exclusively developed perception scale by following likerts scaling technique (Likert et al., 1932). The validity and reliability test was done in study area but with non-sample respondents in order to avoid testing effect. Finally the scale is of fifteen statements and the response for each statements was rated over a five point continuum which ranged from strongly agree to strongly disagree.

The perspective wise score of 180 researchers from sample area was undergone to factor analysis by Exploratory Factor Analysis (EFA) method using SPSS version 23 launched in 2015. Factor analysis is an interdependence technique for identifying clusters of latent variables for a large number of variables in order to bring scientific parsimony. The perspective was used for determining latent factors governing cloning technology of the $\mathrm{j}^{\text {th }}$ respondent by using the given formula:

$\mathrm{Y}_{\mathrm{j}}=\sum_{\mathrm{f}=1}^{\mathrm{f}=\mathrm{n}} \mathrm{a}_{\mathrm{j}, \mathrm{f}} \mathrm{X}_{\mathrm{f}} ; \mathrm{f}=1,2,3, \ldots, \mathrm{n}$

$Y_{j}:$ Perspective of $j^{\text {th }}$ respondent

$a_{j, f}$ : Scoring of the $\mathrm{f}^{\text {th }}$ perspective by $j^{\text {th }}$ respondent

$\mathrm{X}_{\mathrm{f}}: \mathrm{f}^{\text {th }}$ perspective

$\mathrm{n}$ : Number of perspective statement

\section{Results and Discussion}

\section{Brief on personal and socio-economic profile of respondents}

Pooled data showed that more than half $(67.92 \%)$ of the respondents were young age. 73.75 per cent of the respondents were male. More than half $(56.95 \%)$ of the respondents were residing in rural areas. When come to religion aspect, 79.70 per cent were Hindus, 13.50 per cent were Muslims, and 06.81 per cent were belonging to other category. In marital status, 80.83 per cent of respondents were unmarried. About three-fourth $(72.50 \%)$ of the respondents were in nuclear family. In food habit, 60.00 per cent were nonvegetarians, followed by 30.00 per cent were vegetarians, and 10.00 per cent were eggarians.

Most of the respondents perceived that they will trust animal cloning if its approved from the Government of India with a weighted mean score (81.00) and ranked first. Is might be that the researchers believe that still there is need of regulations to authenticate the cloning products. Cloning technology will helpful for saving valuable Germplasm of indigenous breeds (WMS 80.89), the statements portraits the perception of researchers in animal cloning which will helpful in the conserving the germplasm. Respondents also perceive that Cloned animal derivatives are superior to normal animal derivatives with a weighted mean score 77.33. Contradictly researchers also perceive that Animal cloning technology may introduce new organisms that may harmful to society (WMS 75.11).

Animal cloning in food production is good for growth of economy (WMS 66.44),Cloning should be introduced more gradually, even if it missing some of its benefits(WMS 67.44), these two statements were least perceived by 
the respondents as the feels that the animal cloning will helpful to meet the food requirement of future. The perception of the individuals change from time to time and situation to situation hence there is desperate need of wide publicity to bring the changes in the perceptions of public about animal cloned produces. Mellman Group in 2006, Laegsgaardin 2008, Parameswaranaik, in 2019 and Brooks et al., in 2011 have come up with similar findings in their studies.

Table.1 Overview of responses based on respondent's perception towards animal cloning $(\mathrm{n}=180)$

\begin{tabular}{|c|c|c|c|}
\hline S. $\mathbf{N}$ & Statements of perception & $\begin{array}{l}\text { Weighted } \\
\text { mean }\end{array}$ & Rank \\
\hline 1 & $\begin{array}{l}\text { Cloning technology will helpful for saving valuable Germplasm } \\
\text { of indigenous breeds }\end{array}$ & 80.89 & 2 \\
\hline 2 & $\begin{array}{l}\text { The meat, milk and milk products from cloned animals and its } \\
\text { off springs is safe to eat }\end{array}$ & 70.33 & 7 \\
\hline 3 & $\begin{array}{l}\text { Cloned animal derivatives are superior than normal animal } \\
\text { derivatives }\end{array}$ & 77.33 & 3 \\
\hline 4 & $\begin{array}{l}\text { I trust animal cloning if its approved from the Government of } \\
\text { India }\end{array}$ & 81.00 & 1 \\
\hline 5 & $\begin{array}{l}\text { Animal cloning in food production is good for growth of } \\
\text { economy }\end{array}$ & 66.44 & 14 \\
\hline 6 & $\begin{array}{l}\text { Cloning should be introduced more gradually, even if it missing } \\
\text { some of its benefits }\end{array}$ & 67.44 & 13 \\
\hline 7 & $\begin{array}{l}\text { Animal cloning in food production is needed to meet the future } \\
\text { food demands }\end{array}$ & 67.89 & 11 \\
\hline 8 & $\begin{array}{l}\text { Animal Cloning has potential to significantly enhance overall } \\
\text { herd genetics and } \\
\text { population and helps to restore the endangered and extinct } \\
\text { animal species }\end{array}$ & 67.56 & 12 \\
\hline 9 & $\begin{array}{l}\text { Animal cloning should be allowed If the majority of people were } \\
\text { in favour of it }\end{array}$ & 69.67 & 9 \\
\hline 10 & $\begin{array}{l}\text { If anything went wrong with animal cloning it would be a } \\
\text { worldwide Catastrophe }\end{array}$ & 71.78 & 5 \\
\hline 11 & $\begin{array}{l}\text { Animal cloning technology may introduce new organisms that } \\
\text { may harmful to society }\end{array}$ & 75.11 & 4 \\
\hline 12 & $\begin{array}{l}\text { Animal cloning will reduce genetic diversity to an unacceptable } \\
\text { level }\end{array}$ & 68.33 & 10 \\
\hline 13 & $\begin{array}{l}\text { Animal cloning results in animals being viewed as "objects" to } \\
\text { be produced as opposed to being valuable in and of themselves }\end{array}$ & 70.11 & 8 \\
\hline 14 & $\begin{array}{l}\text { Even if cloning animals has benefits it is fundamentally } \\
\text { unnatural }\end{array}$ & 62.33 & 15 \\
\hline 15 & $\begin{array}{l}\text { Deciding on the issue of cloning animals is so complex that } \\
\text { public consultation about it is a waste of time }\end{array}$ & 71.33 & 6 \\
\hline
\end{tabular}


Table.2 Total variance explained

\begin{tabular}{|c|c|c|c|c|c|c|}
\hline \multirow{2}{*}{ Components } & \multicolumn{3}{|c|}{ Initial Eigenvalues } & \multicolumn{3}{c|}{ Extraction Sums of Squared Loadings } \\
\cline { 2 - 7 } & Total & $\begin{array}{c}\text { \% of } \\
\text { Variance }\end{array}$ & Cumulative\% & Total & $\begin{array}{c}\text { \% of } \\
\text { Variance }\end{array}$ & $\begin{array}{c}\text { Cumulative } \\
\text { \% }\end{array}$ \\
\hline Outcome factors & 2.935 & 19.565 & 19.565 & 2.935 & 19.565 & 19.565 \\
\hline Safety factors & 2.290 & 15.269 & 34.833 & 2.290 & 15.269 & 34.833 \\
\hline Democratic factors & 1.900 & 12.665 & 47.498 & 1.900 & 12.665 & 47.498 \\
\hline Futuristic factor & 1.551 & 10.338 & 57.836 & 1.551 & 10.338 & 57.836 \\
\hline Opposing factor & 1.304 & 8.691 & 66.527 & 1.304 & 8.691 & 66.527 \\
\hline Conservation factor & 1.173 & 7.817 & 74.344 & 1.173 & 7.817 & 74.344 \\
\hline Socio-economic factor & 1.071 & 7.143 & 81.487 & 1.071 & 7.143 & 81.487 \\
\hline
\end{tabular}

Table.3 Structured Factor Matrix (SFM)' with Communalities (h2) (n=180)

\begin{tabular}{|c|c|c|c|c|c|c|c|c|}
\hline \multirow[t]{2}{*}{ Statements } & \multicolumn{8}{|c|}{ Component } \\
\hline & 1 & 2 & 3 & 4 & 5 & 6 & 7 & $\mathbf{h}^{2}$ \\
\hline $\begin{array}{l}\text { Saving valuable germplasm } \\
\text { of indigenous breeds }\end{array}$ & -0.114 & 0.115 & -0.008 & 0.075 & -0.018 & 0.885 & 0.091 & 0.917 \\
\hline $\begin{array}{l}\text { Cloned animal derivatives } \\
\text { are superior }\end{array}$ & -0.596 & -0.331 & 0.072 & 0.135 & 0.002 & -0.446 & -0.087 & 0.742 \\
\hline Missing out & -0.300 & 0.350 & 0.536 & 0.657 & -0.294 & 0.346 & 0.256 & 0.792 \\
\hline $\begin{array}{l}\text { Good for growth of } \\
\text { economy }\end{array}$ & 0.010 & 0.205 & 0.026 & 0.008 & 0.090 & 0.185 & 0.888 & 0.894 \\
\hline Approved from GOI & 0.260 & -0.077 & 0.751 & 0.054 & -0.018 & -0.012 & 0.069 & 0.865 \\
\hline Future food demand & 0.066 & -0.474 & 0.361 & 0.648 & 0.090 & -0.224 & -0.356 & 0.823 \\
\hline $\begin{array}{l}\text { Endangered and extinct } \\
\text { animal species }\end{array}$ & 0.712 & -0.270 & 0.021 & -0.078 & -0.225 & -0.286 & 0.069 & 0.634 \\
\hline People were in favour & -0.524 & 0.431 & 0.790 & 0.200 & -0.112 & 0.073 & -0.224 & 0.839 \\
\hline Worldwide Catastrophe & 0.189 & -0.859 & -0.407 & -0.024 & -0.142 & -0.291 & -0.183 & 0.848 \\
\hline Harmful to society & 0.897 & -0.277 & -0.135 & -0.104 & 0.019 & -0.186 & 0.115 & 0.843 \\
\hline Unacceptable level & -0.471 & 0.490 & 0.440 & 0.454 & 0.240 & 0.555 & -0.566 & 0.872 \\
\hline Opposed to being valuable & -0.043 & 0.056 & -0.051 & -0.290 & 0.851 & -0.103 & -0.090 & 0.788 \\
\hline Fundamentally unnatural & -0.010 & 0.145 & -0.133 & -0.074 & 0.770 & 0.138 & 0.210 & 0.708 \\
\hline Public consultation & -0.022 & 0.143 & 0.064 & -0.788 & 0.210 & -0.008 & -0.019 & 0.835 \\
\hline Safe to eat & -0.157 & 0.829 & -0.036 & -0.119 & 0.082 & 0.117 & -0.005 & 0.824 \\
\hline
\end{tabular}

Exploratory factor analysis of researchers towards animal cloning

Suitability test of data for conducting exploratory factor analysis

Before extraction of the exploratory factors, several tests were performed to evaluate the fitness of the researchers response data $(n=180)$ from sample area for EFA. The battery of tests included Kaiser-Meyer-Olkin (KMO) Measure of Sampling Adequacy and Bartlett's Test of Sphericity (BTS). The KMO was employed to figure out whether employing factor analysis to extract latent variables was appropriate or not.

There were 15 statements encompassing perspective and none of the statements were dropped because either their factor loadings 
were $\leq 0.50$ or communalities were $\leq 0.60$. So, the final EFA KMO statistic obtained in this study was approximately 0.5 . Kaiser's specified calibration of the value and according to it, KMOs of the sample selected in this study was adequate for EFA. The BTS was significant $(\mathrm{p}<.001)$ with 1085.486 at 105 df and so factor analysis was established to be apposite.

\section{Exploratory factor analysis following principal component factoring with promax rotation}

After checking suitability of the data among 180 researchers from sample area, EFA was performed to devise outcome following principal component factoring and promax rotation (Table 1). From Table 1 it is evident that seven factors (Eigen values $\geq 1$ ) explained 81.487 per cent variance in the data set, which is pretty above the customary level of 60 per cent. Seven factors are also evident from the scree plots (Fig.1). Only variables with factor loadings (factor-variable correlations) $>0.50$ were used in selecting the factors. Commonly used methods of EFA require estimation of communality values before the process of factor extraction. So, variables having communalities after extraction >0.6 was chosen for the present study.

It would be worth mentioning that primarily 15 statements comprising perspectives were taken and all the statements were selected because they could cross both factor loadings and communalities benchmark. In 1st run EFA 7 different types of latent broad perspectives were identified based on Eigen values $\geq 1$ viz., outcome factors (3 statements), safety factors (2 statements), democratic factors (2 statements), futuristic factors (3 statements), opposing factors (2 statements), conservation factors (1 statement) and socio-economic factors (2 statements) perspectives (Table 2).

Majority of respondents Perceive that they will trust animal cloning if it is approved by GOI, meanwhile researchers also perceived that even cloning is beneficial but it is fundamentally unnatural. The economic and political benefits of comprehending customer's perceptions will be important to successfully placing the product in the market.

These perceptions may vary from time to time based political, social and environmental (climate change) factors. In addition to the perception willingness to pay for cloned animals versus traditional ones is also a vital part to determine the future of food products from animal cloning.

\section{References}

Anderson, J., Wachenheim, C., and Lesch, W. (2006).Perceptions of genetically modified and organic foods and processes. AgBioForum, 9(3), 180-194.

Aro.AR, Hakonen A, and Hietala M (1997). Acceptance of genetic testing in a general population: age, education and gender differences. Pat Educ Couns, 32: 41-49.

Asian Food Information Centre (AFIC, 2003).Consumer perceptions of food biotechnology inAsia: Public report on the AFIC 2002 Consumer Survey.

Ayaz, A., Bilici, S., Uyar, M., Ay, B., Borekci, S., and Kok, E. (2011). Consumer acceptance,knowledge and attitudes towards organic and genetically modified foods: A cross-sectional study among Turkish university students. HealthMED, 5(5), 1014-1021.

Brooks, K. R. and Lusk, J. L. (2011). "U.S.Consumers Attitudes towards Farm Animal Cloning". Appetite, 57:483-492.

Brossard, D., Scheufle, D. A., Kim, E., and Lewenstein, B. V. (2009). Religiosity as a perpetual filter: Examining processes of opinion formation about nanotechnology. Public Understanding of Science, 18(5), 546-558. 
Cobb, M. D., and Macoubrie, J. (2004). Public perceptions about nanotechnology: Risks, benefits and trust. Journal of Nanoparticle Research, 6(4), 395-405.

Condit, C. M. (2010). Public attitudes and beliefs about genetics. Annual Review of Genomics and Human Genetics, 11: 339-359.

Gaskell, G., Eyck, T. T., Jackson, J., and Veltri, G. (2005).Imagining nanotechnology: Cultural support for technological innovation in Europe and the United States. Public Understanding of Science, 14(1), 8190.

Hallman, W.K., Hebden,W.C., Aquino, H.L., Cuite, C., and Lang, J. (2003). Public perceptions of genetically modified foods: A national study of American knowledge and opinion. New Brunswick, NJ: Rutgers Food

Policy

Institute.http://www.pewtrusts.org/uploaded Files/wwwpewtrustsorg/Public_Opinion/Fo od_and_Biotechnology/2006summary.pdf.( aceesed June 14, 2016)

Kasmo, M. A., Usman, A. H., Said, M. M., Taha, M., and Aziz, A. A. (2015). The perception of human cloning: A comparative study between difference faiths in Malaysia. Review of European Studies, 7(3), 178.

Laegsgaard M M and Mors, O.(2008). Psychiatric genetic testing: attitudes and intention among future users and providers. Am J Med Genet B Neuropsychiatry Genet 147: 375-384.

Melanie Sunkyung Kim(2014). "Nanotechnology and food: the perception and level of acceptance of nanotechnology use in foods". Thesis Submitted To The Graduate School - New Brunswick Rutgers, The State University of New Jersey.

Mellman Group. (2006). Review of public opinion research. The Pew initiative on food and biotechnology.

Retrieved

from:http://www.pewtrusts.org/

uploadedFiles/wwwpewtrustsorg/Public_O

pinion/Food_and_Biotechnology/2006sum

mary.pdf.(aceesed June 14, 2016)

Molster C, Charles T, Samanek A, O'Leary $\mathrm{P}(2009)$. Australian study on public knowledge of human genetics and health.

Public Health Genomics, 12: 84-91.

Parameswaranaik J. Senthil Kumar R, Ranvir S.G, Bhawar R.S, Patel Diksha, and Darshan N.P (2015) Exploratory Factor Analysis in Perceptual Understanding of Livestock Rearers towards Climate Variability In Karnataka. International Journal of Agriculture Sciences, ISSN: 0975-3710 \& E-ISSN: 0975-9107, Volume 7, Issue 14, pp.-871-874.

Parameswaranaik, J. (2019). Factors Influencing the Attitude of Return Migrated Rural Youths towards Agripreneurship Development.

Int.J.Curr.Microbiol.App.Sci. 8(07): 28102817. doi: https://doi.org/10.20546/ijcmas.2019.807.3 51

Storey, M. (2006). "Consumers' Knowledge, Attitudes, Beliefs, and Purchase Intent regarding Foods from the Offspring of Cloned Animals". Final Topline Report 2006. Center for Food, Nutrition and Agriculture Policy. University of Maryland College Park.

The Gallup Organization. (2008). Europeans' attitudes towards animal cloning. Analytical report (Flash Eurobarometer Series 238). European Commission. Retrieved from: http://ec.europa.eu/food/food/resources/doc s/eurobarometercloning_en.pdf. (accessed June 14, 2016).

\section{How to cite this article:}

Manu. H. A., H. R. Meena and Priyanka. B. N. 2020. Factorial Analysis of Perceptual Understanding of Researchers towards Animal Cloning. Int.J.Curr.Microbiol.App.Sci. 9(03): 3228-3234. doi: https://doi.org/10.20546/ijcmas.2020.903.369 